\title{
Economic Patterns in U.S. Arboriculture
}

\author{
Christopher M. O'Bryan, Thomas J. Straka, Scott R. Templeton, and Judith D. Caldwell
}

\begin{abstract}
Arboriculture is a distinct industry that provides unique services to provide for the health and care of trees. It is a developing industry and this development leads to questions on how the industry is organized and operates. We define the industry, identify its size and growth patterns, discuss its structure and organization, describe its operation in terms of pricing and competition, and analyze whether it is dominated by large or small firms. This analysis provides important information for regulation and other policies related to arboriculture. The four largest arboricultural firms account for only $4 \%$ of combined industry receipts and the industry comprises nearly 82,000 establishments, employs approximately 160,000 workers, and earns annual gross receipts of nearly $\$ 9$ billion.
\end{abstract}

Key Words. Arboriculture industry; economic structure; industry analysis; utility services; vegetation management.

Within the last century, the commercial practice of arboriculture in the United States has evolved from a few firms that offered specialized tree care services into an industry that consists of several thousand establishments. As the industry develops, certain questions become significant. First, what exactly is the arboriculture industry? It undoubtedly sells tree care services, but different firms offer various types of such service. Second, what are the size and growth patterns of the arboriculture industry? Third, what is the market structure, or organization, of the arboriculture industry? Structure refers to the number of firms in a market, determines how the industry operates, and relates to the degree of competitiveness in the market. These are critical issues when evaluating policy and regulations pertaining to arboriculture. The current literature does not include an analysis of these questions and this article is a first attempt to answer them.

A definition of the arboriculture industry becomes complex when the full spectrum of tree-related services is considered over time. An early manual, The Tree Doctor (Davey 1901), distinguished arboricultural practices from other landscaping practices and emphasized individual tree care (Campana 1999). The Davey Tree Expert Company, established approximately 1880, and the F.A. Bartlett Tree Expert Company, established in 1907, are two of the earliest examples of tree care companies.

Modern arboricultural practices include tree planting, transplanting, fertilizing, pruning, removal, insect and disease management, growth regulation, stump grinding, cabling and bracing, lightning protection, soil management, root pruning, and geographical information system mapping (Shigo 1991). The main objective of arboriculture is the health, appearance, and safety of individual trees.

In 1928, Asplundh Tree Expert Company became the first of a different type of tree care company. It did not offer residential tree care services, but exclusively offered power line clearance or vegetation management services (Campana 1999). Asplundh and several subsequent firms have continued to specialize in this type of utility services.

Utility services differs from arboriculture in that it deals with linear rights of ways rather than individual trees; it uses unit-cost contracts and not bid or flat-flat contracts; and tends to have a wider service area. These differences in objectives, services, contracts, and markets indicate that arboriculture and utility services are separate industries in the United States. This distinction is important because federal data sources often combine the two industries into a single industry called ornamental shrub and tree services (U.S. Census Bureau 2002; Wiatrowski 2005).

\section{STUDY METHODS}

The primary source of industry data in the United States is the U.S. Census Bureau and it does not separate arboriculture and utility services in its data collection. Instead, it collects data for a composite industry that it calls "landscaping services" under its North American Industrial Classification System (NAICS) code of 56173 (U.S. Census Bureau 2006). Landscaping Services is then divided into two general types of businesses: "ornamental shrub and tree services" and "lawn and garden services" (U.S. Census Bureau 2004b). These subcategories are called a product line code, or PLC. Ornamental shrub and tree services (PLC 38252) includes arborist services, ornamental tree and bush planting, pruning, bracing, spraying, removal, and utility-line tree trimming services (U.S. Census Bureau 2002).

Figure 1 illustrates how the U.S. Census Bureau classifies data on the industry. It collects new data every 5 years on the number of establishments whose main business is ornamental shrub and tree service, the total receipts for all types of ser- 


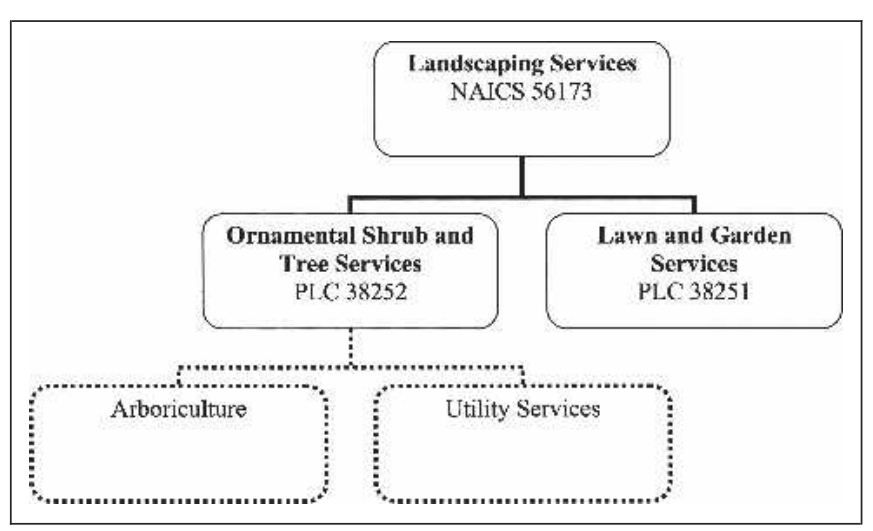

Figure 1. Breakdown of employer data for landscaping services in 2002.

vices that these establishments provide, and the total receipts for ornamental shrub and tree services that were provided by these establishments (U.S. Census Bureau 2004b).

Knowledgeable vice-presidents or analysts from each of the six national companies and six of the regional companies listed in Table 1 were interviewed to estimate the proportion of economic activities attributable to arboriculture and utility services in the U.S. Census Bureau data. Certainly, there is a range around an estimate of this proportion. An article in this Journal included estimates for annual receipts for utility ser-

Table 1. Names or numbers of arboricultural and utility services companies by geographic scope of business. ${ }^{2}$

Geographic

scope

services

Arboriculture

Utility

National

Bartlett Tree Expert Company

Davey Tree Expert Company

The Care of Trees

Regional

Swingle Tree Company
(Rocky Mountains)
Valley Crest Tree
Company
(California)
SavATree (Northeast)

Almstead (Northeast)

McCoy Tree Surgery (Southwest)

Lucas Tree Experts

(Northeast)

Penn Line Service, Inc.

(East)

Wolfe Tree Service

(Great Lakes)

Local $\quad \sim 26,000$ companies

$\sim 1000$ companies vices in the range of $\$ 2$ billion to $\$ 10$ billion (Guggenmoos 2003). A consensus opinion based on the interviews was that utility services had $\$ 2$ billion in receipts and 1000 establishments for 2002. The industry experts felt comfortable providing an estimate for only 2002, so industry growth rate estimates were only calculated at the ornamental shrub and tree services level.

The U.S. Census Bureau collects information on "nonemployer arborists" in a different manner. A "nonemployer arborist" simply refers to a firm with no employees. This is most often a sole proprietorship, but can include a partnership or corporation. Nonemployer arboricultural receipts, establishments, and workers were based on the 2002 Nonemployer Statistics (U.S. Census Bureau 2004a). These data are collected only at the landscaping services level and are not as likely to be as precise as that for employing firms. We also assumed that nonemployers do not participate in the vegetation management industry as a result of stricter regulations and greater capital requirements.

The municipal, or in-house, contribution to arboriculture is estimated from data collected by the Bureau of Labor Statistics for the "tree trimmers and pruners" worker category (Bureau of Labor Statistics 2003) primarily on public employees engaged in arboriculture. The nonprivate categories were estimated to be in-house arboricultural workers and each was assumed to be joined by two additional laborers. Data on in-house establishments were not in the data and, thus, does not appear in our tables.

To calculate real growth (growth over and above inflation) for ornamental shrub and tree services in Table 2, we adjusted the reported receipts for inflation. Reported receipts were in the current year's dollars $(1992,1997$, or 2002) and were obtained from the U.S. Census Bureau (U.S. Census Bureau 2004b, 2005). To obtain real receipts, inflation was subtracted from these reported receipts. The annual Consumer Price Index (CPI), often called the "cost of living," was used to estimate inflation (Bureau of Labor Statistics 2006) and inflation was removed using the standard formula to solve for an interest rate (Straka 2005).

\section{DEFINITION OF VARIABLES}

It is possible for a firm to have receipts from a related activity that is not landscaping services (U.S. Census Bureau 2004b). We only included receipts that related to landscaping services. The ratio of ornamental shrub and tree service receipts to landscaping services receipts is easily obtained from the employer establishment data and was used to categorize receipts from nonemployer companies in Table 3 (U.S. Census Bureau 2004a, 2004b). This method implicitly assumes that the receipt ratio for employer establishments also holds for nonemployer arboricultural receipts. No estimates for municipal arboricultural receipts are presented.

${ }^{\mathrm{z}}$ Definitions of geographic scope levels are in the text. 
Table 2. Growth of ornamental shrub and tree services. ${ }^{z}$

\begin{tabular}{|c|c|c|c|c|c|c|c|}
\hline Year & $\begin{array}{l}\text { Establishments } \\
\text { (number) }\end{array}$ & $\begin{array}{l}\text { Implicit annual } \\
\text { growth rate }(\%)\end{array}$ & $\begin{array}{l}\text { Employment } \\
\text { (number) }\end{array}$ & $\begin{array}{l}\text { Implicit annual } \\
\text { growth rate }(\%)\end{array}$ & $\begin{array}{l}\text { Reported receipts } \\
(\$ 1000)\end{array}$ & $\begin{array}{l}\text { Real receipts } \\
(\$ 1000)\end{array}$ & $\begin{array}{l}\text { Implicit annual } \\
\text { growth rate }(\%)\end{array}$ \\
\hline 1992 & 3951 & \multirow{3}{*}{$11.85 \%$} & 49,416 & & $3,014,376$ & $3,865,191$ & \multirow{3}{*}{$1.09 \%$} \\
\hline & & & & $4.48 \%$ & & & \\
\hline 1997 & 6916 & & 61,519 & & $3,639,841$ & $4,079,797$ & \\
\hline 2002 & 26,372 & $30.69 \%$ & 149,123 & $19.37 \%$ & $9,504,199$ & $9,504,199$ & $18.43 \%$ \\
\hline
\end{tabular}

${ }^{\mathrm{z}}$ Definitions of column titles are in the text.

${ }^{\mathrm{y}}$ All dollar amounts in 2002 dollars.

Establishment refers to a business address and not necessarily a firm. A single firm may have several establishments. The estimated number of utility services establishments (1000) was subtracted from the total number of ornamental shrub and tree service establishments to arrive at the number of arboricultural establishments. The number of nonemployer arboricultural establishments was calculated using the assumptions that each nonemployer worker corresponds to an individual establishment and that the ratio defined also applies to nonemployer arboricultural workers. We acknowledge that this method may be somewhat imprecise, but it is the most reasonable proportioning device available (Carlton and Perloff 2005).

Estimates for numbers of employees pose the same problem as for establishments. The ratio applied was also used to estimate the total number of workers employed in arboriculture. This estimate depends on the assumptions that receipts earned per employee in arboriculture are identical to receipts earned per landscape worker, and the ratio of support personnel per landscape worker is identical between ornamental shrub and tree services and lawn and garden services. Like previously stated, there is some level of impreciseness, but this is the most logical method. The end result does include utility services workers and these (based on expert opinion as mentioned previously) must be subtracted. The total employ- ment for the arboricultural industry was estimated with the following equation:

$$
\mathrm{AE}=((\mathrm{OSR} / \mathrm{LSR}) * \mathrm{LE})-\mathrm{VE})+\mathrm{NE}+\mathrm{ME}
$$

where AE is total arboricultural employees, OSR is the total ornamental shrub and tree service receipts, LSR is the total landscaping services receipts, LE is the employment for landscaping services, VE is the estimated employment for utility services, NE is the estimated employment for nonemployer arboricultural services, and ME is the estimated employment for in-house arboricultural services.

The geographical scope in which arboricultural firms conduct business varies from local to international. Local firms conduct business within a local geographical region, usually defined by daily driving range. Local firms typically own one or a few establishments within one or a few states and employ fewer than 100 workers if the firm is in the arboricultural industry or fewer than 400 workers if the firm is in the utility services industry. Regional firms conduct business in multiple states. Regional arboriculture firms typically own several establishments in a few states and employ 100 to 499 workers. Regional utility services firms typically employ 400 to 3499 workers. National arboricultural companies typically own several establishments in several states across regions in the United States and employ more than 500 workers in the

Table 3. Quantitative breakdown of the arboriculture and utility services industries based on data and definitions from the text, 2002.

\begin{tabular}{|c|c|c|c|c|c|c|}
\hline Code & Structural tier & $\begin{array}{l}\text { Establishments } \\
\text { (number) }\end{array}$ & $\begin{array}{l}\text { Receipts } \\
(\$ 1000)\end{array}$ & $\begin{array}{l}\text { Employees } \\
\text { (number) }\end{array}$ & $\begin{array}{l}\text { Receipts per } \\
\text { establishment }\end{array}$ & $\begin{array}{l}\text { Employees per } \\
\text { establishment } \\
\text { (number) }\end{array}$ \\
\hline NAICS 561730 & Landscaping services (employer) & 76,458 & $35,235,452$ & 514,962 & $\$ 461,000$ & 6.7 \\
\hline PLC 38251 & Lawn and garden services & 67,986 & $23,316,436$ & 365,839 & 343,000 & 5.4 \\
\hline \multirow[t]{2}{*}{ PLC 38252} & Ornamental shrub and tree services & 26,372 & $9,504,199$ & 149,123 & 360,000 & 5.7 \\
\hline & Utility services & 1000 & $2,000,000$ & 53,900 & $2,000,000$ & 53.9 \\
\hline \multirow[t]{3}{*}{ NAICS 561730} & Landscaping services (nonemployer) & 209,072 & $4,811,183$ & 209,072 & 296,000 & 1.0 \\
\hline & Arboriculture services (employer) & 25,372 & $7,504,199$ & 95,223 & 296,000 & 3.8 \\
\hline & Arboriculture services (nonemployer) & 56,394 & $1,297,740$ & 56,394 & 23,000 & 1.0 \\
\hline \multirow[t]{2}{*}{ BLS 37-3013 } & In-house arboriculture services & & & 5,400 & & \\
\hline & Total arboriculture industry & 81,766 & $8,801,939$ & 157,017 & & \\
\hline
\end{tabular}

Sources: U.S. Census Bureau (2004a, 2004b; Bureau of Labor Statistics 2003). 
arboricultural industry or more than 3500 workers in the utility services industry. The names or numbers of national, regional, and local companies that specialize in arboriculture or vegetation management are presented in Table 1 .

The four-firm concentration ratio (C4) is commonly used to measure the market structure of industries (Demsetz 1973; Weiss 1989; Salinger 1990). The C4 is the share of an industry's sales that are accounted for by the four largest firms (Carlton and Perloff 2005) and, thus, the $\mathrm{C} 4$ for arboriculture would represent the receipts of the four largest (measured by receipts) arboriculture firms divided by the receipts of all (national, regional, and local) arboricultural firms. The $\mathrm{C} 4$ could be used to test the hypothesis that a single arboricultural company or small group of them influences the prices of arboricultural services (Levy 1985) and there are numerous examples of using the C4 for this purpose (Curry and George 1983).

Quantitative measures of the arboriculture and utility services industries are presented in Table 3. Receipts per establishment, employees per establishment, and receipts per employee are self-explanatory. Receipts per employee hour were calculated by dividing the receipts per employee by 2000 hours (40 hours per week times 50 weeks).

\section{RESULTS AND DISCUSSION}

Ornamental shrub and tree services, the combination of arboriculture and vegetation management, has seen tremendous growth in numbers of establishments, employees, and real receipts (Table 2). Between 1992 and 2002, the annual growth rate of number of establishments was $21 \%$, number of employees was $12 \%$, and real receipts was $9 \%$. For the second half of that period, annual growth rates increased substantially (Table 2).

Figure 2 shows the breakdown of landscaping services into industry segments by establishments, receipts, and employees. Arboricultural services accounted for just over onefourth of establishments and roughly one-fifth of receipts and employees. Arboriculture firms with employees average almost four workers per establishment and, although they are outnumbered by single-employee arboriculture firms by more than two to one, their receipts exceeded the single-employee firm by nearly six to one in 2002 (Table 3). In economics terms this is called increasing returns to scale. As number of employees increase, production increases at a greater rate. Factors like division of labor and better use of equipment allow for these efficiencies. This is also called economy of scale and it means there will be a decreased unit cost as output increases.

Figure 3 illustrates that the arboriculture firms with employees, when compared with single-employee and in-house arboriculture services, produce most of the industry's receipts with $61 \%$ of the employees. The average employing arboricultural establishment posted $\$ 296,000$ in receipts in 2002 . The data in Table 3 can be used to calculate averages. For example, arboriculture establishments with employees posted an average of $\$ 39.40$ in receipts per employee hour representing annual receipts per employee of $\$ 78,807$. Table 3 shows that arboriculture employees account for the bulk of receipts and likely are the most highly skilled workers of the landscaping services industry (Bureau of Labor Statistics 2005).

Nonemployer arboriculture firms, which are counted as both establishments and employees, may outnumber those with employees but receipts are substantially less (Table 3 ). With just over one-third of employees, they account for less than one-sixth of receipts in the arboriculture industry (Figure $3)$. Receipts per employee hour are calculated at $\$ 11.51$, considerably lower than employing arboriculture firms (Table 3). Nonemployers may have less stringent income reporting requirements and are less likely to work only 2000 hours per work year (Smith and Reither 1996). Nonemployers may include some individuals who are full-time employees of established firms and who perform some tree care work on the side.

In-house arboricultural employees are estimated to be only $3 \%$ of the total arboriculture industry (Figure 3). More detailed analysis of the in-house sector is not possible with currently available data.

The national arboricultural firms earned $4 \%$ of total receipts in the United States in 2002 and the C4 ratio is also only $4 \%$ (Table 3 ). Obviously, the top four firms used to calculate the $\mathrm{C} 4$ closely represent the national firms. Local firms dominate the national and regional firms in term of receipts in 2002 (Figure 4). If the arboriculture industry operated in one market that was national in scope, then the four-firm concentration ratio might be interpreted as consistent with the hypothesis that arboriculture is a relatively competitive industry. This is a very low $\mathrm{C} 4$ ratio, which usually indicates an industry operating under perfect competition. This compares with agriculture with a $\mathrm{C} 4$ ratio of about $5 \%$ and overall landscaping services with a $\mathrm{C} 4$ ratio of $10.8 \%$ (U.S. Census Bureau 2002). However, total receipts of C4 firms and national firms do not correspond to revenues in one national market but primarily to revenues from thousands of local and tens of regional markets. The dominance of singleemployee arboriculture firms that require minimal startup capital (truck and chain saw) is evidence of a pricecompetitive industry (Demsetz 1982).

The number of nonemployer companies participating in arboriculture and their corresponding receipts per employee hour suggest that the capital requirement necessary to participate in the industry are at least initially relatively low. As the company grows and hires employees, additional costs such as workers' compensation insurance become necessary. It follows that nonemployer companies should be able to offer services at a lower price. That is, profit incentives exist for nonemployer companies. Why then should an arborist organize as a firm to hire workers at all? There are relatively small economies of scale of management and average cost 


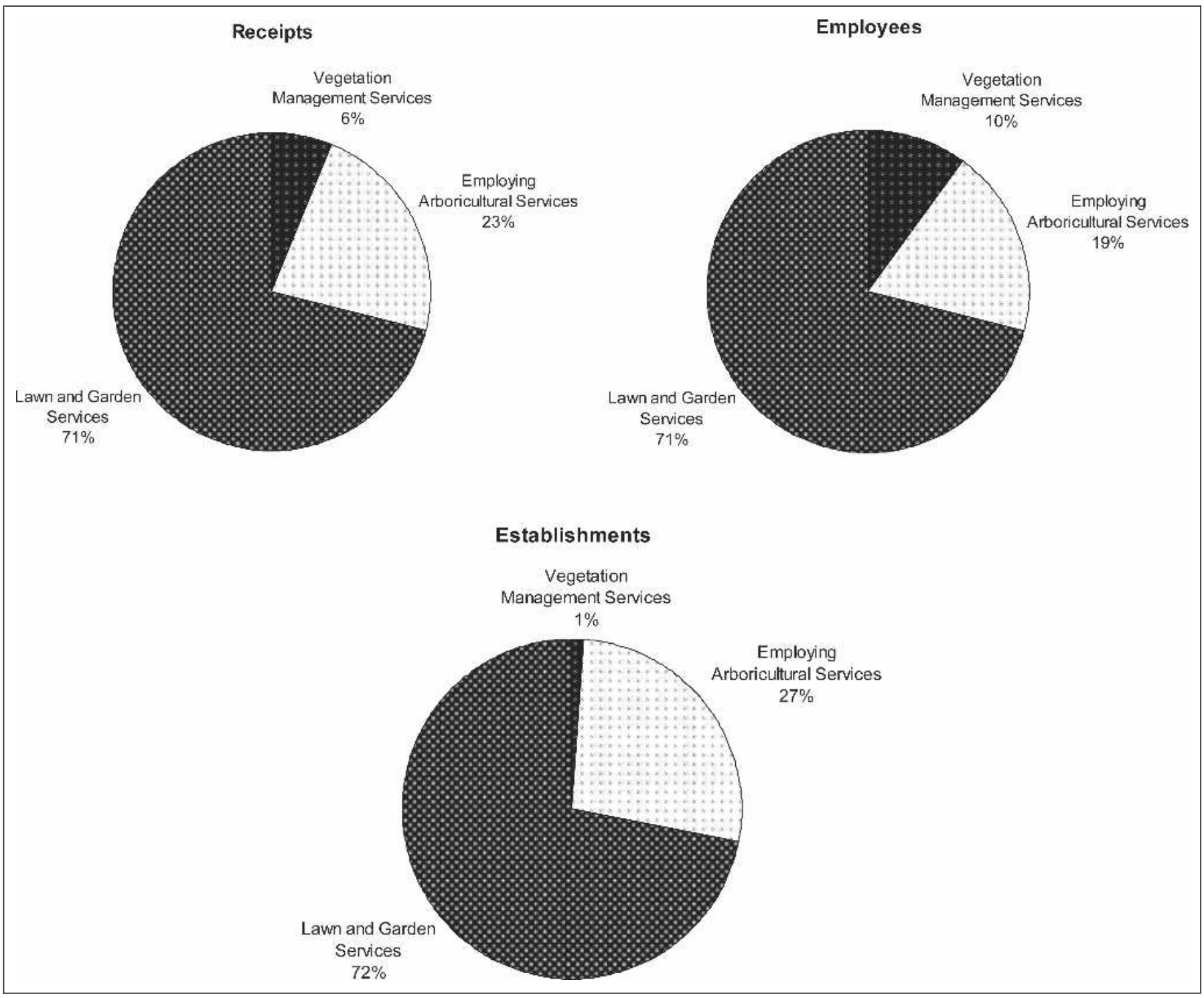

Figure 2. Landscaping services (NAICS 56173) data for employing firms in 2002 (ornamental shrub and tree services is the combination of vegetation management services and employing arboricultural services) (U.S. Census Bureau 2004b).

would be expected to fall as number of employees increases, up to a point. Also, customer expectations may play a role. Arboriculture work is often hazardous, and a more riskadverse customer may demand that the service provider have workers' compensation insurance, liability insurance, and industry certifications. Employing firms are more likely to possess these characteristics than nonemployer companies. Arboriculture work often requires additional persons working together as a crew to complete a job. Also, as an arborist ages, the physically demanding work may necessitate employee assistance. Employing firms likely have a greater ability to provide additional workers on a consistent basis and might want to specialize in types of services or differentiate their services as higher quality by employing industry-certified workers. Customers' expectations about risk and labor management and their effects on prices of arboricultural services within a market require further study.

Our results are consistent with other studies of the "green industry." Economies of scale, barriers to entry, and market structures are generally similar across the industry (Florkowski and Landry 2000). Arboriculture does have several predominant firms, but the $\mathrm{C} 4$ ratio showed that they do not foster a climate that tends to limit price competitiveness. Arboriculture is part of a dynamic green-industry but has a fairly firm market structure that will adapt as customer needs dictate (Singh 1999). 


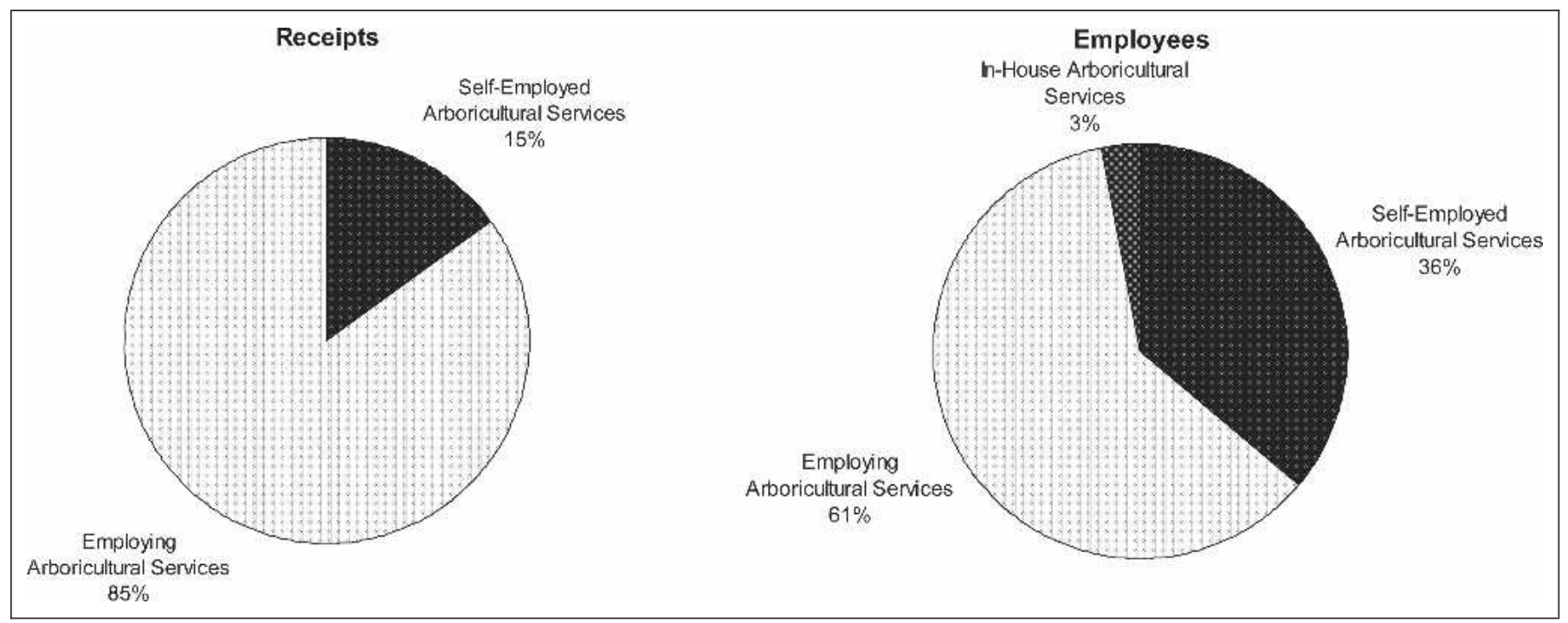

Figure 3. Estimated receipts in arboricultural industry in 2002 (employing, self-employing, and in-house establishments) (U.S. Census Bureau 2004a, 2004b; Bureau of Labor Statistics 2003.)

\section{UTILITY SERVICES}

This analysis produced 2002 estimates for utility services of approximately 1000 establishments, $\$ 2$ billion in receipts, 53,900 employees, $\$ 2$ million in receipts per establishment, 53.9 employees per establishment, and $\$ 18.55$ in receipts per employee hour (Table 3). The utility services industry has fewer receipts per employee hour than the arboriculture industry, perhaps as a result of the high level of mechanism generally used in utility services operations. Utility services accounted for $1 \%$ of establishments, $6 \%$ of receipts, and $10 \%$ of employees within landscaping services (Figure 2).

Three utility services firms that have establishments in multiple regions represent an $87 \%$ market share and the four- firm concentration ratio is $92 \%$. The top four firms dominate the market for line-clearing services. Regional firms represent an $11 \%$ market share, and local firms represent a $2 \%$ market share (Figure 4). Utility services industry establishments must possess the means to mobilize large numbers of workers and equipment to fulfill relatively large contractual agreements. These conditions favor fewer larger firms.

\section{CONCLUSION}

We have characterized the arboriculture and utility services industries as similar but distinct. Both are growing industries with their main differences being in terms of receipts per employee and the $\mathrm{C} 4$ ratio. We also suggested they are sepa-

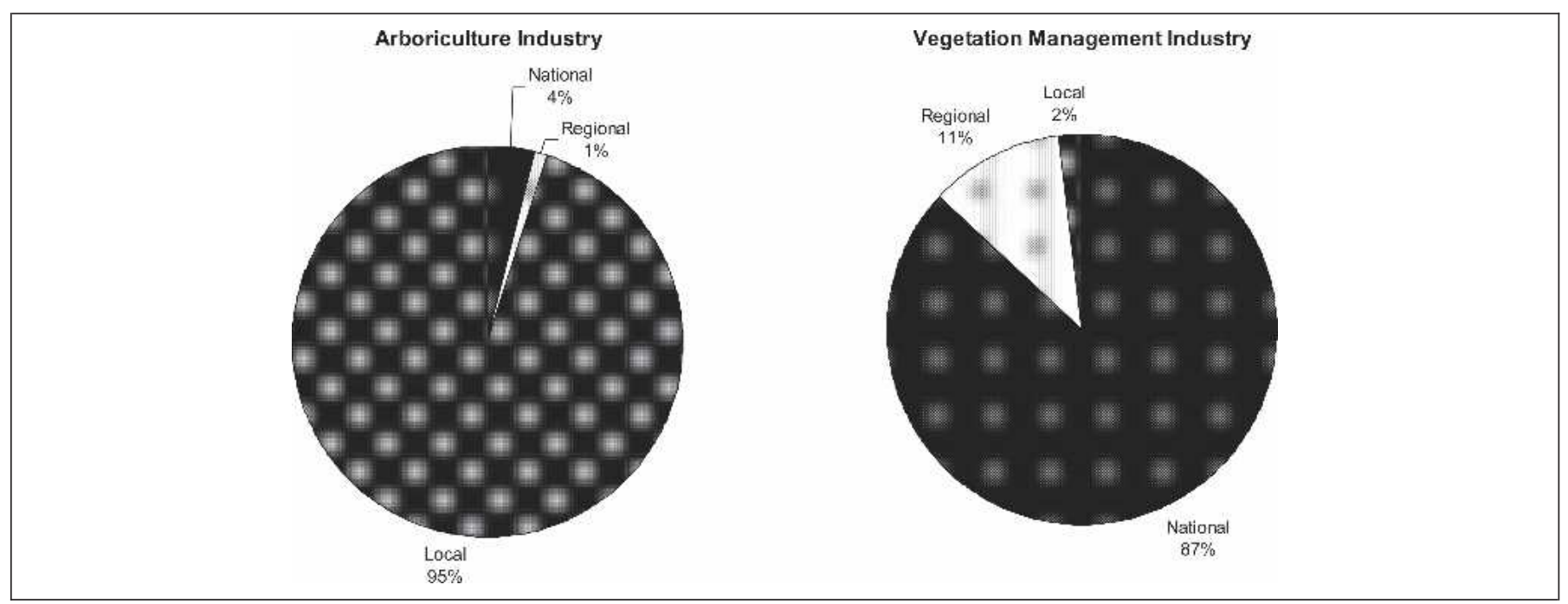

Figure 4. Local, regional, and national firms' shares of receipts for arboriculture and vegetation management (U.S. Census Bureau 2004b). 
rate in terms of services, contracting methods, markets, and structure.

If this distinction is accurate, the current U.S. Census Bureau data do not allow both industries access to reliable economic data. In the past, ornamental shrub and tree services had a separate six-digit NAICS code just like landscaping services does now. It was treated as a separate industry and not part of landscaping services. Reinstatement of the NAICS code for ornamental shrub and tree services would mean economic data would be available every year instead of every 5 years. Furthermore, if the ornamental shrub and tree services was then separated into arboriculture and utility services (i.e., assigning each a separate PLC), each industry would be provided with relevant numbers of establishments, employees, and gross receipts every 5 years.

There is another advantage to assigning a NAICS code to ornamental shrub and tree services. Injuries and fatalities are an important aspect of tree-related services, but since 2003, the U.S. Department of Labor began reporting this data at the NAICS or landscaping services code level. In 2002, they reported fatalities of 70 workers for ornamental shrub and tree services, or an estimated fatality rate of 32.9 per 100,000 workers (Department of Labor 2005). In 2003, the fatality rate for landscaping services was 14.1 per 100,000 workers compared with an overall rate of 4.0 for all workers in all industries (Wiatrowski 2005). The annual fatality rate for tree workers has consistently been at or above 30 per 100,000 for several years (Ball and Vosberg 2003). Because tree-related work is significantly more dangerous than other landscaping activities, generalizing fatality data into landscaping services likely hinders the evaluation of safety programs developed to reduce tree work fatalities.

Growth and size patterns are important because they define future markets and industry composition. These results will allow a firm's owner to better evaluate its position in the industry. While considering the structure of their industry (national versus regional and local markets), the owner may ask, "How do my receipts per employee hour compare with the national average? or "Am I above or below average size?" Industry pricing and competition operate to define the business environment of arboriculture. Policy and regulation issues can only be addressed when information of this type is available. This analysis provides evidence to describe this ever-developing industry.

Acknowledgments. Support for this research was provided by The TREE Fund Hyland R. Johns Grant Program. Staff members of the International Society of Arboriculture and the Tree Care Industry Association were very helpful in provid-

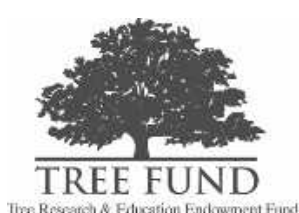
ing data and insights. David Marren, Bartlett Tree Expert Company, and many other tree care and vegetation management managers and analysts provided valuable information pertaining to industry structure.

\section{LITERATURE CITED}

Ball, J., and S. Vosberg. 2003. How accidents happen and why: Arboricultural safety in the United States. Tree Care Industry 14:50-54.

Bureau of Labor Statistics, U.S. Department of Labor. 2003. Occupational Employment and Wages. www.bls.gov/oes/ 2002/oes373013.htm (accessed 5/22/06).

- 2005. Occupational Outlook Handbook, 2006-2007 ed. Bulletin 2600. Government Printing Office, Washington, DC.

- 2006. Consumer Price Indexes. www.bls.gov/cpi/ home.htm (accessed 7/11/06).

Campana, R.J. 1999. Arboriculture: History and Development in North America. Michigan State University Press, East Lansing, MI.

Carlton, D.W., and J.M. Perloff. 2005. Modern Industrial Organization. 4th ed. Addison Wesley, New York, NY.

Curry, B., and K.D. George. 1983. Industrial concentration: A survey. The Journal of Industrial Economics 31: 203-255.

Davey, J. 1901. The Tree Doctor: A Book on Tree Culture. Commercial Printing Company, Akron, $\mathrm{OH}$.

Demsetz, H. 1973. Industry structure, market rivalry, and public policy. The Journal of Law \& Economics 16:1-9.

— 1982. Barriers to entry. The American Economic Review 72:47-57.

Florkowski, W.J., and G. Landry. 2000. An Economic Profile of the Professional Turfgrass and Landscape Industry in Georgia. University of Georgia Agricultural Experiment Station Research Report No. 672.

Guggenmoos, S. 2003. Effects of tree mortality on power line security. Journal of Arboriculture 29:181-196.

Levy, D. 1985. Specifying the dynamics of industry concentration. The Journal of Industrial Economics 34:55-68.

Salinger, M. 1990. The concentration-margins relationship revisited. Brookings Papers on Economic Activity. Microeconomics 1990:287-335.

Shigo, A.L. 1991. Modern Arboriculture: A Systems Approach to the Care of Trees and Their Associates. Shigo and Trees, Associates, Durham, NH.

Singh, S.P. 1999. The changing structure of the U.S. green industry: Factors influencing opportunities and issues. Journal of International Food and Agribusiness Marketing 10:65-83.

Smith, P.A., and C.L. Reither. 1996. Comprehensive income and the effect of reporting it. Financial Analysts Journal 52:14-19.

Straka, T.J. 2005. Forest products financial decisions: Inflation in investment analysis. Forest Products Equipment 13:33-35.

U.S. Census Bureau, U.S. Department of Commerce. 2002. Definitions. www.census.gov/econ/census02/naics/ sector56/56173.htm (accessed 7/11/06). 
. 2004a. 2002 Economic Census, Advance Nonemployer Statistics, Table 1: Summary and Legal Form of Organization for the United States. www.census.gov/ epcd/nonemployer/2002adv/us/US000_56.HTM (accessed 7/11/06).

2004b. Services to Buildings and Dwellings: 2002. 2002 Economic Census, Administrative and Support and Waste Management and Remedial Services, Industry Series, EC02-561-07. www.censusgov/prod/ec02/ec0256i07t. pdf (accessed 7/11/06).

- 2005. County Business Patterns. www.census.gov/ epcd/cbp/view/cbpview.html (accessed 7/11/06).

- 2006. Industry Statistics Sampler, NAICS 561730, Landscaping Services. www.census.gov/econ/census02/ data/industry/E561730.HTM\#T1 (accessed 7/11/06).

U.S. Department of Labor. 2003. Occupational Employment and Wages, 2002. www.bls.gov/oes/2002/oes373013.htm (accessed 5/22/06).

- 2005. Census of Fatal Occupational Injuries, All Worker Profile: 1992-2002 (revised). www.bls.gov/iif/ oshwc/cfoi/cftb0186.pdf (accessed 5/22/06).

Weiss, L.W., Ed. 1989. Concentration and Price. MIT Press, Cambridge, MA.

Wiatrowski, W.J. 2005. Fatalities in the Ornamental Shrub and Tree Services Industry. U.S. Department of Labor, Bureau of Labor Statistics, Washington, DC. www.bls. gov/opub/cwc/sh20050719ar01p1.htm (accessed 5/22/06).

Christopher M. O'Bryan

Graduate Research Assistant

Department of Forestry and Natural Resources

Clemson University

PO Box 340317

Clemson, SC 29634-0317, U.S.

Thomas J. Straka (corresponding author)

Professor

Department of Forestry and Natural Resources

Clemson University

PO Box 340317

Clemson, SC 29634-0317, U.S.

tstraka@clemson.edu

Scott R. Templeton

Associate Professor

Department of Applied Economics and Statistics

Clemson University

PO Box 340313

Clemson, SC 29634-0313, U.S.

stemple@clemson.edu
Judith D. Caldwell

Associate Professor

Department of Horticulture

Clemson University

PO Box 340319

Clemson, SC 29634-0319, U.S.

jcldwll@clemson.edu

Résumé. L'arboriculture est une industrie distincte qui fournit des services uniques en entretien et en santé des arbres. C'est une industrie en développement et ce développement mène à des questions sur le comment cette industrie fonctionne et opère. Nous avons définit cette industrie, identifié sa taille et son modèle de croissance, discuté de sa structure et de son organisation, décrit son fonctionnement en terme de prix et de compétition, et analysé si elle était dominée par de petites ou de grandes entreprises. Cette analyse fournit une information importante pour la réglementation et autres politiques relatives à l'arboriculture. Les quatre plus grosses entreprises comptent pour seulement $4 \%$ des revenus combinés de l'industrie qui compte au total environ 82000 entreprises employant approximativement 160000 travailleurs pour un chiffre d'affaire global de près 9 milliards de dollars.

Zusammenfassung. Baumpflege ist eine besondere Industrie, die einen einmaligen Service zur Gesundung und Pflege von Bäumen liefert. Es ist eine sich entwickelnde Industrie und diese Entwicklung führt zu Fragen, wie diese Industrie organisiert ist und operiert. Wir definieren diese Industrie, identifizieren ihre Größe und Wachstumsformen, diskutieren ihre Struktur und Organisation, beschreiben ihre Operationen in Bezug auf Preis und Wettbewerb und analysieren, ob es durch kleine oder große Firmen dominiert wird. Die Analyse liefert wichtige Informationen für Regulation und andere Regeln, die mit Baumpflege verbunden sind. Die vier größten Baumpflegefirmen erwirtschaften nur $4 \%$ der kombinierten Aufträge und die Industrie verspricht jährlich 82.000 Engagements, beschäftigt schätzungsweise 160.000 Arbeiter und erwirtschaftet jährlich nahezu \$ 8 Mill. Dollar.

Resumen. La arboricultura es una industria especial de servicios únicos que proporcionan salud y cuidado a los árboles. Es una industria en desarrollo que permite responder a preguntas de cómo se organiza y opera. Definimos la industria, identificamos su tamaño y patrones de crecimiento, discutimos su estructura y organización, describimos su operación en términos de comercio y competencia, y analizamos si está dominada por grandes o pequeñas firmas. Este análisis provee información importante para la regulación y otras políticas relacionadas con la arboricultura. Las cuatro empresas más grandes responden por solamente el 4 por ciento de los ingresos y la industria comprende aproximadamente 82,000 establecimientos, emplea aproximadamente 160,000 trabajadores, y obtiene ingresos brutos anualmente por $\$ 9$ billones de dólares. 